\title{
Treatment of Vagus Nerve Stimulator Pocket Infection without Removal of the Hardware
}

\author{
(1) Martin BLAHA, () Michal TICHY
}

Department of Neurosurgery, University Hospital Motol, Charles University Second Medical Faculty, Prague, Czech Republic

\begin{abstract}
Summary
The management of postoperative pocket infections after vagus nerve stimulator implantation is challenging. Most patients present within four weeks after the implantation of the device and Staphylococcus aureus is the most common infecting agent. Standard medical practice involves the complete hardware removal and antibiotics to achieve long-term cure, with the subsequent reimplantation of the device. Attempts to treat these infections without the removal of the hardware led to high infection recurrence rates because of the formation of staphylococcal biofilms on the device. We present a case of vagus nerve stimulator infection treated successfully with a single surgical debridement of the infected wound and six weeks of antibiotic treatment, but without removing the hardware.
\end{abstract}

Keywords: Biofilms; epilepsy; epilepsy surgery; infection; rifampicin; vagus nerve stimulation.

Cite this article as: Blaha M, Tichy M. Treatment of Vagus Nerve Stimulator Pocket Infection without Removal of the Hardware. Epilepsi 2021;27:62-65.

\section{Introduction}

Vagal nerve stimulation (VNS) has been shown to be effective for seizure reduction in epileptic patients with poorly controlled seizures. ${ }^{[1-4]}$ Invasive VNS requires implantation of a VNS therapy generator (stimulator) and a lead-electrode (Cyberonics Inc., LivaNova PLC, London, England, UK). The generator is usually placed into the subcutaneous pocket on the chest and the stimulating electrode is wrapped around the left vagal nerve in the mid cervical region and connected to the generator. Postoperative infection occurs in $2 \%-6 \%$ of patients and it is the most serious complication to consider. ${ }^{[5-10]}$ The precise and effective treatment for a VNS hardware infection is still unclear. Standard medical practice involves the complete removal of the hardware and antibiotics to achieve long-term cure, with the subsequent reimplantation of the device. ${ }^{[6,10,11]}$ This approach may increase the risk of vagal nerve injury during

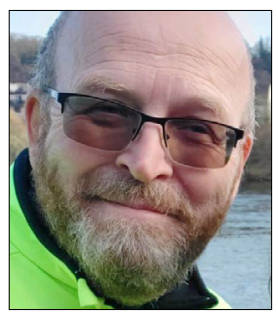

Corresponding author Martin BLAHA, M.D.

e-mail drmartinblaha@yahoo.com

Received 29.02.2020

Accepted 29.06.2020

Online date 22.01.2021

Content of this journal is licensed under a Creative Commons Attribution-NonCommercial 4.0 International License.

Dr. Martin BLAHA

C 2021 Turkish Epilepsy Society electrode removal and subsequent electrode reimplantation. ${ }^{[6,12,13]}$ There is also a significant increase in medical cost when the reimplantation of a new VNS device is needed. Moreover, the potential benefits of VNS are postponed until a new reimplantation, and some patients may lose confidence and resign from this method. Therefore, treatment without hardware removal would be very desirable. Antibiotics alone mostly suppress the infection in the short-term, but with a high rate of recurrence $(73 \%-100 \%)$ requiring hardware removal. ${ }^{[14,15]}$ To avoid the potential morbidity of following two repeated carotid sheath surgical dissections, Wozniak et al. ${ }^{[16]}$ suggested a lead-salvage protocol that involves generator removal and antibiotic therapy without lead removal. Ortler et al. ${ }^{[17]}$ published the successful treatment of a VNS device infection without hardware removal. The cervical wound was treated with open wound debridement. Next, the wound was packed with $3 \%$ iodoformized gauze, systemic antibiotic therapy was started, and the wound was rinsed daily with $3 \%$ hydrogen peroxide and $5 \%$ saline until delayed primary closure two weeks later. We would like to present the case of a patient with a VNS hardware infection that was successfully treated with antibiotics and only a single surgical procedure, but without any device removal, while emphasizing the importance of the biofilm role in infection recurrence. 


\section{Vagus Sinir Stimülatörü Cep Enfeksiyonunun Cihaz Çıkarılmadan Tedavisi}

Özet

Vagus sinir stimülatörü implantasyonundan sonra ortaya çıkan postoperatif cep enfeksiyonlarının yönetimi zordur. Hastaların çoğu, cihazın implantasyonundan sonraki 4 hafta içinde başvurur ve Staphylococcus aureus en yaygın enfeksiyon ajanıdır. Standart tıbbi uygulamada uzun vadeli iyileşme sağlanması için önce cihaz tamamen çıkarılır ve antibiyotik kullanılır, daha sonra cihazın yeniden implante edilir. Cihazın çıkarılmadan enfeksiyonların tedavi edilmesine yönelik girişimler, cihazın üzerindeki stafilokok biyofilm oluşumuna bağlı olarak yüksek oranda enfeksiyon nüksü getirir. Bu çalışmada, enfekte yaranın tek cerrahi debridman ve altı haftalık antibiyotik tedavisiyle donanım çıkarılmadan başarıyla tedavi edildiği bir vagus sinir stimülatörü enfeksiyonu vakası sunulmaktadır.

Anahtar sözcükler: Biyofilmler; epilepsi; epilepsi cerrahisi; enfeksiyon; rifampisin; vagus sinir stimülasyonu.

\section{Case Report}

A 41-year-old man with medically intractable epilepsy was evaluated in our comprehensive epilepsy surgery program and indicated for vagus nerve stimulation. His seizures were associated with tachycardia; therefore, he was scheduled for implantation of Aspire SR ${ }^{\circledast}$ Model 106 (Cyberonics Inc., LivaNova PLC, London, England, UK). His epileptic syndrome was considered not to be feasible for resection surgery. He suffered from Tick-borne encephalitis at the age of 11 years and subsequently developed complex partial seizures with secondary generalization. The patient was under long-term care by a dermatologist for psoriasis.

On April 25, 2018, the VNS device Aspire SR ${ }^{\circledR}$ Model 106 (Cyberonics Inc., LivaNova PLC, London, England, UK) was implanted in a standardized fashion. VNS generator was placed in the subcutaneous pocket in the left infraclavicular space. All the wounds were rinsed with saline throughout the procedure. As perioperative antibiotic prophylaxis, we used intravenous Cefuroxime $1.5 \mathrm{~g}$. The surgical intervention lasted for 70 minutes and ran through smoothly without any complication. The patient was discharged on postoperative day 2 (POD 2) and sutures were removed on POD 12 by a local general surgeon.

Three weeks after the implantation, on May 17, 2018, the patient was seen by his neurologist during a regular visit. Due to the significant swelling and fluid collection around his generator pocket wound, he was referred immediately to the neurosurgical outpatient clinic. Besides the gently reddish and swollen infraclavicular wound, the patient was well. C-reactive protein was normal $(0.7 \mathrm{mg} / \mathrm{L})$ and white blood cells count was 6.5 per $\mathrm{mm}^{3}$. Twenty milliliters of yellowish fluid was punctured and microscopic evaluation revealed cell debris, erythrocytes, leukocytes, and sporadically gram-positive cocci. Oral Augmentin (amoxicillin/ clavulanate potassium) $2 \mathrm{~g}$ BID (twice a day) was started. Within four days, the final microbiological evaluation showed an infection with Staphylococcus aureus, and the subcutaneous fluid collection was completely replenished.

After discussing with the patient and his father, we decided to treat the infection without the complete removal of the VNS hardware. On May 22, 2018, under local anesthesia, the infraclavicular wound was opened and the fluid collection was evacuated. The VNS generator was disconnected and mechanically wiped off with a sterile gauze to remove any emerging biofilm formation on the VNS hardware. The subcutaneous pocket including the visible part of the electrode and generator was copiously irrigated several times; firstly with hydrogen peroxide, then with $10 \%$ povidone-iodine solution, and finally with gentamicin solution. A surgical sharp spoon was used for surgical debridement of the cavity walls until the surrounding tissue was slightly bloody. The wound was rinsed with hydrogen peroxide, then with $10 \%$ povidone-iodine solution, and finally with gentamicin solution again. The VNS generator was connected to the electrode and inserted back into the subcutaneous pocket. Mini Redovac ${ }^{\circledR}$ (B.Braun, Melsungen, Germany) was used for low vacuum wound drainage and the skin was closed in one layer with monofilament non-absorbable sutures. Antibiotic therapy was initiated with intravenous Oxacillin $4 \mathrm{~g}$ QID (four times a day) and oral Rifampicin $300 \mathrm{mg}$ TID (three times a day). Rifampicin was started because it is the most effective drug against staphylococcal biofilms. ${ }^{[18-20]}$ Wound drainage was removed on POD 4. Wound healing went uneventfully and there were no further local or general signs of infection. The patient was discharged home on POD 9

Table 1. Algorithm for the treatment of VNS infections

1. Administration of intravenous antibiotics alone

2. Open wound treatment without the hardware removal + antibiotics

3. Lead salvage technique + antibiotics

4. Complete device removal + antibiotics

Antibiotics - intravenous Rifampicin in combination with another antibiotic to prevent the development of resistance. 
and antibiotic therapy was switched to only oral form - Rifampicin $300 \mathrm{mg}$ TID and Ofloxacin $400 \mathrm{mg}$ BID for an additional five weeks of treatment. Sutures were removed on POD 14 in our outpatient clinic. The further clinical course was favorable without any clinical or laboratory signs of infection. One-and-half year follow-up showed a decreased frequency of complex partial seizures with secondary generalization.

\section{Discussion}

Complications of vagus nerve stimulation are related to surgery or to stimulation of the vagus nerve..$^{[5-13,16,21,22]}$ Postoperative infection causes considerable morbidity. Most of the patients present within four weeks after the implantation of the device and S. aureus is the most common infecting agent. ${ }^{[15]}$ Low body mass index and low intelligence quotient were identified as risk factors for VNS infection. ${ }^{[23]}$ It is very useful to compare the VNS literature with a similar medical field-cardiac implantable electronic devices (CIEDs). There are $>500000$ CIEDs implantation in the United States every year; therefore, the data analysis can be very impactful. ${ }^{[24]}$ Pocket infection after the CIEDs implantation has been published from $0 \%$ to $12.6 \%$ (mostly ranging from $1 \%$ to $7 \%$ ). ${ }^{[25-28]}$ The most common infecting agent after the implantation of cardiac devices is also S. aureus in $60 \%-80 \%$ of cases. ${ }^{[29-31]} \mathrm{A}$ recent meta-analysis of 5467 patients receiving CEIDs implantation showed an infection rate of $2.34 \%$. ${ }^{[32]}$ Pooled data revealed a significant difference between pocket irrigation with antimicrobial solutions (infection rate was $1.48 \%$ ) and the saline irrigation group (3.49\%). We can presume that pocket irrigation with antibiotics may be effective for reducing pocket infection and should be encouraged. Management of postoperative infection after spinal instrumentation shows also similar features to VNS device infections. The incidence of wound infection after 452 procedures was $3.8 \%$ and the most common organism cultivated was S. aureus (53\%). ${ }^{[33]}$ The current treatment consists of operative debridement of the infected wound, a course of intravenous followed by oral antibiotics, insertion of an antibiotic-containing irrigation-suction system, and maintenance of the instrumentation system within the infected wound.

We report the case of a patient with a typical clinical picture of VNS device pocket infection. The patient was treated successfully without the hardware removal, but with a single surgical debridement of the infected wound and six weeks of antibiotic treatment. There are no definite general recommendations for VNS device infection, but this case report demonstrates VNS hardware salvage and a cost-effective procedure. Open wound treatment without the hardware removal is a possible alternative to complete device removal, lead-salvage technique, or antibiotic treatment alone (Table 1). Rifampicin is the most effective drug against staphylococcal biofilms and it could be preferred.

Informed Consent- Informed consents of patient were received.

Peer-review- Externally peer-reviewed.

Conflict of interest- The authors declare that they have no conflict of interest.

Authorship Contributions- Concept: M.B., M.T.; Design: M.B., M.T.; Supervision: M.B., M.T.; Data collection \&/or processing: M.B., M.T.; Analysis and/or interpretation: M.B., M.T.; Literature search: M.B., M.T.; Writing: M.B., M.T.; Critical review: M.B., M.T.

\section{References}

1. Boon $P$, Vonck K, Vandekerckhove $T, D^{\prime}$ have $M$, Nieuwenhuis $L$, Michielsen $G$, et al. Vagus nerve stimulation for medically refractory epilepsy; efficacy and cost-benefit analysis. Acta Neurochir (Wien) 1999;141(5):447-52. [CrossRef]

2. Landy HJ, Ramsay RE, Slater J, Casiano RR, Morgan R. Vagus nerve stimulation for complex partial seizures: surgical technique, safety, and efficacy. J Neurosurg 1993;78(1):26-31.

3. Penry JK, Dean JC. Prevention of intractable partial seizures by intermittent vagal stimulation in humans: preliminary results. Epilepsia 1990;31 Suppl 2:S40-3. [CrossRef]

4. Uthman BM, Wilder BJ, Penry JK, Dean C, Ramsay RE, Reid SA, Hammond EJ, Tarver WB, Wernicke JF. Treatment of epilepsy by stimulation of the vagus nerve. Neurology 1993;43(7):1338-45.

5. Ben-Menachem E. Vagus-nerve stimulation for the treatment of epilepsy. Lancet Neurol 2002;1(8):477-82. [CrossRef]

6. Couch JD, Gilman AM, Doyle WK. Long-term Expectations of Vagus Nerve Stimulation: A Look at Battery Replacement and Revision Surgery. Neurosurgery 2016;78(1):42-6. [CrossRef]

7. Kahlow $\mathrm{H}$, Olivecrona $\mathrm{M}$. Complications of vagal nerve stimulation for drug-resistant epilepsy: a single center longitudinal study of 143 patients. Seizure 2013;22(10):827-33. [CrossRef]

8. Révész D, Rydenhag B, Ben-Menachem E. Complications and safety of vagus nerve stimulation: 25 years of experience at a single center. J Neurosurg Pediatr 2016;18(1):97-104. [CrossRef]

9. Smyth MD, Tubbs RS, Bebin EM, Grabb PA, Blount JP. Complications of chronic vagus nerve stimulation for epilepsy in children. J Neurosurg 2003;99(3):500-3. [CrossRef]

10. Yang J, Phi JH. The Present and Future of Vagus Nerve Stimulation. J Korean Neurosurg Soc 2019;62(3):344-52. [CrossRef]

11. Elliott RE, Morsi A, Kalhorn SP, Marcus J, Sellin J, Kang M, et al. Vagus nerve stimulation in 436 consecutive patients with treatment-resistant epilepsy: long-term outcomes and predictors of response. Epilepsy Behav 2011;20(1):57-63. [CrossRef] 
12. Aalbers MW, Rijkers K, Klinkenberg S, Majoie M, Cornips EM. Vagus nerve stimulation lead removal or replacement: surgical technique, institutional experience, and literature overview. Acta Neurochir (Wien) 2015;157(11):1917-24. [CrossRef]

13. Giordano F, Zicca A, Barba C, Guerrini R, Genitori L. Vagus nerve stimulation: Surgical technique of implantation and revision and related morbidity. Epilepsia 2017;58(Suppl 1):85-90.

14. Air EL, Ghomri YM, Tyagi R, Grande AW, Crone K, Mangano FT. Management of vagal nerve stimulator infections: do they need to be removed? J Neurosurg Pediatr 2009;3(1):73-8.

15. Patel NC, Edwards MS. Vagal nerve stimulator pocket infections. Pediatr Infect Dis J 2004;23(7):681-3. [CrossRef]

16. Wozniak SE, Thompson EM, Selden NR. Vagal nerve stimulator infection: a lead-salvage protocol. J Neurosurg Pediatr 2011;7(6):671-5. [CrossRef]

17. Ortler M, Luef G, Kofler A, Bauer G, Twerdy K. Deep wound infection after vagus nerve stimulator implantation: treatment without removal of the device. Epilepsia 2001;42(1):133-5.

18. Jacqueline C, Caillon J. Impact of bacterial biofilm on the treatment of prosthetic joint infections. J Antimicrob Chemother 2014;69(Suppl 1):i37-40. [CrossRef]

19. Jørgensen NP, Skovdal SM, Meyer RL, Dagnæs-Hansen F, Fuursted K, Petersen E. Rifampicin-containing combinations are superior to combinations of vancomycin, linezolid and daptomycin against Staphylococcus aureus biofilm infection in vivo and in vitro. Pathog Dis 2016;74(4):ftw019.

20. Zimmerli W, Sendi P. Role of Rifampin against Staphylococcal Biofilm Infections In Vitro, in Animal Models, and in Orthopedic-Device-Related Infections. Antimicrob Agents Chemother 2019;63(2):e01746-18. [CrossRef]

21. Seçen $A E$, Aslan A, Bulduk EB, Yıldırım I, Serdaroğlu A, Kurt $G$. Lead fractures after vagal nerve stimulator implantation. Epilepsi 2019;25(3):136-40. [CrossRef]

22. Nalbantoğlu M, Özkara Ç, Yeni N, Demirbilek V, Yalçınkaya C, Delil Ş, et al. Efficacy of vagus nerve stimulation in patients with drug resistant epilepsy. Epilepsi 2014;20(1):23-8. [CrossRef]

23. Kuroda N, Fujimoto A, Okanishi T, Sato K, Itamura S, Baba S, et al. Low Body Mass Index and Low Intelligence Quotient Are Infection Risk Factors in Vagus Nerve Stimulation. World Neurosurg 2019;130:e839-45. [CrossRef]
24. Tarakji KG, Wilkoff BL. Management of cardiac implantable electronic device infections: the challenges of understanding the scope of the problem and its associated mortality. Expert Rev Cardiovasc Ther 2013;11(5):607-16. [CrossRef]

25. Cabell CH, Heidenreich PA, Chu VH, Moore CM, Stryjewski $\mathrm{ME}$, Corey GR, et al. Increasing rates of cardiac device infections among Medicare beneficiaries: 1990-1999. Am Heart J 2004;147(4):582-6. [CrossRef]

26. Chua JD, Wilkoff BL, Lee I, Juratli N, Longworth DL, Gordon SM. Diagnosis and management of infections involving implantable electrophysiologic cardiac devices. Ann Intern Med 2000;133(8):604-8. [CrossRef]

27. Karchmer AW, Longworth DL. Infections of intracardiac devices. Cardiol Clin 2003;21(2):253-71. [CrossRef]

28. Ra'Ad T, Elena D, Kasra M, Monali P, Victor M. In-Hospital mortality among patients receiving an implantable cardioverter-defibrillator in the United States: 2000 to 2012. J Am Coll Cardiol 2016;67(13):862. [CrossRef]

29. Baddour LM, Cha YM, Wilson WR. Clinical practice. Infections of cardiovascular implantable electronic devices. N Engl J Med 2012;367(9):842-9. [CrossRef]

30. Bloom HL, Constantin L, Dan D, De Lurgio DB, El-Chami M, Ganz $\mathrm{LI}$, et al; COoperative Multicenter study Monitoring a CIED ANtimicrobial Device Investigators. Implantation success and infection in cardiovascular implantable electronic device procedures utilizing an antibacterial envelope. Pacing Clin Electrophysiol 2011;34(2):133-42.

31. Schwartzman D, Pasculle AW, Ceceris KD, Smith JD, Weiss LE, Campbell PG. An off-the-shelf plasma-based material to prevent pacemaker pocket infection. Biomaterials 2015;60:1-8.

32. Kang FG, Liu PJ, Liang LY, Lin YQ, Xie SL, He Y, et al. Effect of pocket irrigation with antimicrobial on prevention of pacemaker pocket infection: a meta-analysis. BMC Cardiovasc Disord 2017;17(1):256. [CrossRef]

33. Levi AD, Dickman CA, Sonntag VK. Management of postoperative infections after spinal instrumentation. J Neurosurg 1997;86(6):975-80. [CrossRef] 